\title{
Social Research in the Light of the German Sociologist Georg Simmel in Comparison with Chinese Sociology
}

\author{
Ferdinand Fellmann \\ Chemnitz University, Chemnitz, Germany \\ Email: rebeccawalsh24@yahoo.com
}

How to cite this paper: Fellmann, F. (2018) Social Research in the Light of the German Sociologist Georg Simmel in Comparison with Chinese Sociology. Open Journal of Social Sciences, 6, 230-242. https://doi.org/10.4236/jss.2018.612020

Received: November 15, 2018

Accepted: December 25, 2018

Published: December 28, 2018

Copyright $\odot 2018$ by author and Scientific Research Publishing Inc. This work is licensed under the Creative Commons Attribution International License (CC BY 4.0).

http://creativecommons.org/licenses/by/4.0/

\section{(c) (i) Open Access}

\begin{abstract}
The German sociologist and philosopher Georg Simmel (1858-1918) is internationally known as the founder of Formal Sociology. I take the centenary of his death as a welcome opportunity to remember the beginning of modern social sciences. The current state of European and American relational sociology can be interpreted as a revival of Simmel's method and principles of social research directed to a phenomenology of genesis. From the genetic point of view Simmel considers individuality, creativity, fragmentation and conflict the typical characteristics of modern society. Consequently, his Formal Sociology should be called "Genetic Sociology" instead of Relational Sociology. This paper has the aim to make Simmel's legacy known to Chinese sociologists and cultural philosophers. Concluding, I highlight the essential differences between the German and the Chinese way of seeing the world of social life, and I propose issues for change.
\end{abstract}

\section{Keywords}

Genetic Sociology, Interaction, Conflict, Reciprocity, Subjective Culture, Objective Culture, Sexual Life, Image of Man

\section{Introduction: Georg Simmel's Way of Life and Thought}

Georg Simmel taught at the University of Berlin, the cultural ferment of the period from the turn of the century to World War I. His lectures were frequented by a broad public, mostly by intellectual women who were fascinated by the teacher's aura. Simmel's actuality is doubtless due to the unscholarly aspects of Simmel's style of life and thinking. He lived a bourgeois life with his wife, their home becoming a venue for cultivated gatherings in the tradition of the salon. 
The couple exemplified the intellectual marriage of the period, celebrating the freedom of independent partners, as Sartre and Simone de Beauvoir were to do after World War II. The newly gained sexual liberty paved the way to Simmel's late philosophy of culture.

Simmel's thought is divided into three phases: First, his positivistic method of social research, which ends with the 1905 edition of his epistemological essay The Problems of the Philosophy of History [1]; second, his relational method of social research culminating in his 1908 Sociology Investigations of the Forms of Sociation [2]; third, philosophical essays dealing with the concept of culture in the last years until his death in 1918 [3] [4]. The nucleus of Simmel's philosophy of culture is present in his most famous work, The Philosophy of Money (1900) [5]. Simmel viewed money as a means of economic exchange and as such as a symbolic form that enables an understanding of the evolution of modern culture. Whereas sociology considers the formal aspects of social interaction, cultural anthropology takes into account the personal background of social organization. This view derives from the close relation between economy and human passions. Their common feature is the dynamic of the will to live. This structural equivalence turns money into the basic metaphor of human existence that connects subjective culture with objective culture according to the principle of reciprocity.

Simmel was convinced that sexual life, the most private feature of personality, is at the root of all cultural forms. His whole system of social interaction is centered around erotic love based on the male-female polarity, which means that man and woman are equal in rights but are different in function and in emotionality. In his late essays Simmel explains how, through the sexual revolution of his time, the cultural evolution has achieved its highest level in the relation between life and form. He is convinced that modern erotic life flows in individual channels and is directed against forms which force life into generalized schemata and thereby destroy its individuality. Simmel's devotion to the principle of individuality has given social research a new key that may be of use for modern Chinese sociology [6].

It is noteworthy that the libidinous undercurrent of Simmel's conception of social life has seldom been noticed. Neither his contemporaries nor his later interpreters pay attention to the fact that Simmel's personality was that of an erotic shaped by the way of urban life. Of course, Simmel's theories are not a direct projection of his personal life but his academic nonconformity sheds light on his way of seeing the social world through the lens of his temperament. Simmel's theory of erotic love is indispensable for understanding the way society grows bottom up as a system of different strata of cultural life.

\section{The Concept of Society}

Simmel was an outstanding innovator in methodology. He does not consider society as an institutionalized structure but he is concerned with the emergence of 
social forms from interaction between individuals to satisfy their emotional needs. His 1908 book: Soziologie. Untersuchungen über die Formen der Vergesellschaftung (Sociology: Inquiries into the Construction of Social Forms) is a collection of essays that are held together by the question how is society possible [2]. Simmel's answer is: because sociation is felt by people as their natural environment. Viewed from the sociological perspective this self-evidence requires biological, psychological and logical explanations. Simmel's explanations are the following: First, human behavior is regulated by rigid patterns of natural drives. Second, the natural impulses are modified by psychological workings of interpersonal relationships. And third, the developmental behavior patterns follow the logic of geometrical forms. The forms contain subordination, super-ordination, exchange, conflict and association by which a sum of separate individuals is made into a higher unity. Social integration has formed and is performed by different social types such as the stranger, the adventurer etc. The notion of the stranger has found wide usage in modern sociological literature. Simmel defines the stranger as a member of the group he lives in and yet remains distant from the native members of the group. At the present time of migration, this social type is highly relevant.

In the chapter "The Quantitative Determination of the Group" Simmel analyses how the number of persons in a group is qualitatively experienced. In a two-person group ( $d y a d)$ each partner is able to retain their individuality. Since in this case each person has only another individual by his side, the group's dependence on him, and consequently his responsibility for common action, is obvious. In a three-person group (triad) there is a possibility of weakening the remaining individual's independence and causing him to become the subordinate of the group. The analysis of three-person groups leads Simmel to consider networks of groups as higher social structures. In society, as the groups become increasingly greater, the individual becomes separated and grows more alone, isolated and segmented.

Simmel's view was somewhat ambiguous with respect to group size. On one hand he believed that the bigger the group the better for the individual. In a larger group it would be harder to exert control on the individual, but on the other hand with a large group there is a possibility of the individual becoming distant and impersonal. Therefore, in an effort to cope with the enlargement of the group, the individual strives to be at home in a smaller group such as the family.

Concerning intimate relations, the urban style of life in big cities like Berlin, where Simmel spent most of his life, leads to futile sexual encounters with no commitment at all. Simmel was aware of the fact that this way of life in the long run leads to social fragmentation, which undermines the cohesion of the community. But at the same time, it frees people from the social ties of traditional class structure and opens the door for the development of spontaneous intimacy. It is this state of nearness through distance that gives people the opportunity to develop new forms of self-validation and self-expression. 
Unlike in Western sociology the concept of society in Chinese sociology is strongly shaped by the current constitution of the People's Republic of China. Thus, Chinese sociology has a strong focus on applied, policy-oriented research. Key topics include the changing social stratification in China, social organizations and social governance, family and demographic studies, migration and urbanization, cultural and ideological change, social security and social justice. Society as a totality is a gradual concept that gives a justification for focus upon socio-economic developments. In this field, Chinese sociology is on the right path. On the other hand, there is a notable lack of theoretical basics in Chinese concepts of society. Relational sociology as the study of forms of social interaction or sociation is not yet fully established. Here the acquaintance with Simmel's work will help to pave the way to the primacy of Chinese social research.

To sum up: The fabric of society, as Simmel conceives it, relies on interactions between individuals. The dynamic relation is experienced prior to the relata, and according to the act of exchange follows the pattern of reciprocity. The group is a whole which is more than the sum of the elements, beginning with the couple as a two-person group and ending with society as a group of indefinite size. This is, in short, the leading idea of Simmel's formal sociology that has been at the beginnings of relational sociology. But as we will see, this is not the best term for Simmel's way of interpreting the growth of the social world.

\section{The Concept of Culture and the Dynamic of Life}

In the light of the many aspects of human behavior Simmel considers society near to culture. Although the analysis of social facts dominates his sociology, whereas cultural forms dominate his more philosophical writings, a rigid separation is not to be found. In the perspective of genetic phenomenology, Simmel refers to culture as a process of cultivation of individuals through the agency of external forms like religion, art, or science. This was the beginning of cultural sociology practiced by Weimar Germany sociologists such as Alfred Weber [7]. Social and political organizations as well as rituals of celebrations generate archetypical forms of all human sociality, called "patterns of culture" by Ruth Benedict (1934).

In his book The Philosophy of Money Simmel distinguishes between two forms of culture: subjective or personal culture and objective culture [5]. Subjective culture as the domain of authentic individuality has priority. Despite the primacy of individuality subjective culture is not self-contained. It can only develop with the help of objective factors, especially money as a structuring agent of cultural life. Here objective culture is ambiguous. On the one hand it tends to be a runaway process leaving behind any subjective experience. Personal identity is fragmented and dissolved into a network of exchange governed by quantifiable monetary value. On the other hand, paradoxically, this results in greater potential freedom of choice for the individual, as money can be deployed toward any possible goal. Money's homogenizing nature encourages greater liberty and 
equality, even as it minimizes exceptional, incommensurable achievements in artistic forms of living.

In his 1903 lecture The Metropolis and Mental Life Simmel explains the complex relation between personality and objective culture. Referring to his Philosophy of Money, he writes: "The deepest problems of modern life flow from the attempt of the individual to maintain the independence and individuality of his existence against the sovereign powers of society, against the weight of the historical heritage and the external culture and technique of life. The antagonism represents the most modern form of the struggle which primitive man must carry on with nature for his own bodily existence" [8]. The self-preservation of the individual brings human experience in permanent conflicts. The inevitable conflicts are destructive and constructive as well. They are constructive in giving society texture, durability, and resilience. But the increase of objective social structures such as legal systems or technology is intensely felt as a threat to individuality. This double face of experience provides the very basis for life to attain its self-transcending character. "From more-life to more-than-life" is Simmel's formula to describe this process. The driving force of cultural evolution could well be called libidinous, in the specific sense of eroticism as well as in the broader sense of the will to live.

In the 1911 essay On the Concept and the Tragedy of Culture Simmel argues that cultural forms emerge in social interactions and become fixed [9]. As such they stand in perpetual tension with the ongoing life processes, which tend to break off from old forms and to create new ones. Thus, the concept of culture implies that the mind ("Geist") creates objective entities through which the development of the subject takes the way from itself to itself. This is the normal course of life. Sometimes the continual creation of new forms is stopped by the rigidity of the forms. This is the point where the cultural process becomes tragic. The tragedy of culture consists in the fact that the destructing forces directed against life arise from the deeper stratum of life itself. Thus, the forms with which human life has built up its own positivity become self-destructive negativity.

Strangely enough, Simmel in his later essay The Conflict in Modern Culture (1918) shows modern culture in a more positive light. The key concept in this essay is "life" in its spiritual sense, mental life. In contrast to the biological meaning, mental life is always connected with opposed qualities or tendencies stemming from an originally undifferentiated unity: "Whenever life progresses beyond the animal level to that of the spirit, and the spirit progresses to the level of culture, an internal contradiction appears. The whole history of culture is the working out of this contradiction. We speak of culture wherever life produces certain forms in which it expresses and realizes itself [...]. These forms are frameworks for the creative life which, however, soon transcends them" [8]. Conflict is essential for change in spiritual life, understanding conflict as "struggle in the absolute sense of the term which encompasses the relative contrast 
between war and peace" [8]. Conflict and reciprocity as two intimately related forms of interaction make continual morphogenesis the leading idea of Simmel's philosophy of life.

Simmel points out that in modern times the creative dynamic of life has become so powerful that it does not only modify its forms and create new ones, but strives to get rid of every form at all. This, according to Simmel, does not function in the long run, because it is a self-contradiction and would lead to flow without firm borders, which are necessary for culture to go on. Especially the sexual life as practiced by the new generation tends to break down the normal life-form-dualism. Consequently, modern eroticism seems to lead to sexual promiscuity and anarchic lust. But upon closer consideration it becomes clear that free love overcomes alienation: "Genuine erotic life in fact flows naturally in individual channels. Opposition is directed against forms because they force it into generalized schemata and thereby overpower its uniqueness. The struggle between life and form is fought here less abstractly and less metaphysically as a struggle between individuality and generalization" [8]. This is a characteristic turn of Simmel's endeavor to make abstract social categories more concrete. In this sense sociology turns out to be cultural sociology as practiced by early theorists like Karl Marx and Emile Durkheim.

Simmel's formal sociology underpinned by the philosophy of culture calls attention to the ambiguity of his work wavering between essays and systematic works. Chinese sociology to the contrary is free from this problematic access. The current sociology journals: Journal of Sociological Research (JSR) (Shehuixue Yanjiu, published since 1986) and Society (Shehui, since 1982) are not culturally orientated at all. Since society and culture are considered more or less identical topics, Chinese social science proceeds in the analytic-functional way of normal science. But the question how cultural sociology can help to reform Chinese socials research is becoming more and more urgent [10].

\section{Sexuality and Eroticism}

In view of the life-form-dialectic of culture Simmel considers sexual life as basic to the growth of sociability. Unlike Sigmund Freud's libido theory centered on infantile sexuality, Simmel holds on to love between adults. The basic characteristic of erotic love is individuality. Humans do not have sex with some member of the opposite sex; they make love to a special individual. For loving people sexual intercourse represents the total personality. Lovers strive to synthesize the vital and the formal; the mere quantity of orgasmic achievements is overcome by the quality of emotional affection. Subjective experience of loving activity is engaged with desire's dissonance apt to embrace emotional flow and creativity.

In the above mentioned second chapter of Sociology: Inquiries into the Construction of Social Forms, Simmel explains his sociological view of marriage. Unlike pragmatic forms of association, marriage binds the spouses together but this bond allows the development of individual freedom. In a long note Simmel 
traces the peculiar form of marriage back to the ambiguous character of the sexual act: "The peculiar combination of subjective and objective, personal and super-personal or general elements in marriage is involved in the very process that forms its basis physiological pairing. It alone is common to all historically known forms of marriage, while perhaps no other characteristic can be found without exceptions. On the one hand, sexual intercourse is the most intimate and personal process, but on the other hand, it is absolutely general, absorbing the very personality in the service of the species and in the universal organic claim of nature. The psychological secret of this act lies in its double character of being both wholly personal and wholly impersonal. It explains why it is precisely this act that could become the basis of the marital relation which, at a higher sociological stage, repeats the same duality." Simmel sees an analogy in the aesthetic formation of the artists, and he resumes: "But among sociological formations, marriage seems to be the only one, or at least the purest, of this type. Here all cases of a given social form really contain only one common element; but this element is not sufficient to realize the form. This form emerges, rather, only when something else, something inevitably individual, which is different from case to case, is added to the general" [2].

This passage is crucial for understanding Simmel's attending to a genetic phenomenology of social life. He considers social life made of strata of existence, beginning with the germ line and ending in spirituality. New and complex functions arise through the integration of simpler levels which far from disappearing continue to function as fundamental components of the new entity. This is the case of sexuality as a biological need which humans share with animals, but transform it into eroticism that equals creativity, as it stimulates the imagination of intimate situations. That indicates that human sexuality has passed beyond the act of procreation and has become self-conscious. On the other side the preponderance of the erotic bond may suppress the potentials of the personality that lie outside the erotic sphere. In erotic love nature and culture are entangled in a dialectic way making the mating mind unique.

Simmel's sociological and psychological view of erotic love has been empirically confirmed by later life sciences. Ethnology has shown that the sexual drive is a natural force that is active in all areas of culture. For Bronislaw Malinowski, author of Sex and Repression in Savage Society, psychosexuality has paved the way to a dynamic theory of the human mind and its unconscious sides [11]. Modern sociobiology considers Darwinian sexual selection as only one factor in the evolution of sociability. Edward O. Wilson in his classic Sociobiology. The New Synthesis has demonstrated, how the antagonism between sex and sociality, mostly displayed by animals, is mitigated in human society by the cultural forms of courtship [12]. In evolutionary biology the transformation of the sexual drive into eroticism characteristic for intimate relations is considered as an important presupposition of humanization [13]. Eroticism, unlike mere sexual activity, is a psychological issue dependent on, and at the same time independent of, sexuality. 
The step from sexuality to eroticism opens the door to human individuation and free will.

In the essay The Relative and the Absolute in the Gender-Problem Simmel links sexuality to sex differences. In opposition to casual sex ("the relative"), sexuality connected with eroticism shapes the person as a whole and harmonizes all aspects of sexual behavior: "The absolute represents sexuality or eroticism as cosmological principle" [14]. The sex differences become manifest in the way sexuality is dealt with. The sexual drive is dominant in men, whereas women perceive sexual arousal as secondary. This is because female sexuality rests more in itself and is consequently not in need of the relation to man. The being-in-itself of the "more profound female sexuality" refers to the potential maternity of the woman, but Simmel goes a step further in exalting female sexuality as a metaphysical principle which overcomes sexual relativity and elevates the absoluteness of the female Eros to the unity of being.

In his most successful essay Flirtation (Die Koketterie), published 1911 in the collection Philosophische Kultur, Simmel discusses flirtation as a generalized type of interaction. According to Simmel, "to define flirtation as simply a 'passion for pleasing' is to confuse the means to an end with the desire for this end." The distinctiveness of the flirt lies in the fact that the coquette awakens delight and desire by means of a unique antithesis and synthesis: through the alternation of accommodation and denial. In the behavior of the flirt, the man feels the proximity and interpenetration of the ability and inability to acquire something. According to this, flirtation is the sophisticated form of the courtship process typically marked by a mixture of desire and coyness. Flirtation is not merely evident in the coquette, but also in intellectual life, in the sort of self-concealment in which a person stands behind what is expressed in a veiled fashion. Of course, flirtation is particularly significant in human relationships where rigid codes of sexual behavior exist. It was a means by which the power of "consent or refusal" could be exercised by women: "Flirtation is a means of enjoying this power in an enduring form." When men engage in flirtation, it becomes a game or a form of playing with reality. Like art, which places itself beyond reality, "flirtation also does no more than play with reality, yet it is still reality with which it plays" [14]. From this follows that undetermined behaviors are not negative per se but play a positive role in human social interactions like love and friendship.

Similar to the development of European eroticism in the last century, sexuality in China has undergone dramatic changes [15]. Changes in this field consider not only sexual behaviors and attitudes but also a series of related social changes such as gender equality. As sociology of sexuality is not in the focus of social research, only personal reflections or argumentative essays are at hand. However, from a sociological perspective, there have been several main factors that have created the current turning point of changing sexual culture in the contemporary Chinese social context [16]. 


\section{Ethics and the Image of Man}

The impact of Simmel's work on contemporaries mainly concerned his formal sociology. The basic forms of social interaction were widely discussed. In US-American sociology Simmel was present especially through the mediation of Robert Ezra Park [17]. On the whole, individual behavior was not in the focus of Simmel's reception. An exception to be noted is a work by Murray S. Davis, Intimate Relations (1973). Following Simmel's microscopic method, Davis analyzes the psychological factors by which personal relations evolve. Partners in a pair-bonded state lose their old selves in each other by creating each other anew. In this process of individuation people do not follow strict moral rules. Instead they are motivated by the ideal construction of their relationships. In this the whole person comes into play, and in modern couples, it is the wife whose role is increasingly dominant.

In various essays Simmel deals with the contributions of women to culture. Whereas objective culture is marked by male contradiction and restlessness, subjective culture is associated with female harmony and stability. Simmel's polarized psychology of maleness and femaleness has been modified by differential psychology and is in the strict sense no longer valid. Nevertheless, Simmel recognizes the dominance of female sociability in modern times that has overcome the patriarchal bias of traditional culture. In modern societies, where female sensibility equals male purpose, the female personality norms tend to become the general scheme of moral norms. This corresponds to Simmel's late "ideal turn", which he expressed in his 1913 article Law of the Individual. An attempt on the principle of ethics [9].

In this essay (literally translated "Individual Law") Simmel argues against Immanuel Kant's theory that there is a single moral obligation, the "Categorical Imperative", relying on the concept of duty [18]. This position is analogous to Confucian virtue ethics that eliminates emotions from the right way to humanity [19]. Simmel, to the contrary, points out that humans are not only guided by reason but by emotions as well, some of which are tonic and constructive. Among the basic emotions like anger, fear, disgust, etc., love is unique as it must be shared by a loving partner. Only in a state of loving and being loved can individuals experience themselves as whole persons with rights and obligations to others. This is the primordial root of ethics, which does not regard exclusively what a person does but what he or she is. One's being or character may be better than one's actions, and concrete ethics have to take that into account.

An extended version of the 1913 article appeared in Simmel's final work, The View of Life (1918) [20]. Here, Simmel replaces the opposition of "is" and "ought" by that of reality and ought, both being two modes of personal life with equal rights. By inverting Kant's Categorical Imperative, Simmel is convinced to produce an ethics of authentic individuality. Kant's moral imperative is working top down from pure reason, which Kant declared as universal but which in reality is male. Simmel's individual law on the contrary is emerging bottom up from 
concrete situations dominated by female sense and sensibility. This position may be called "Genetic Ethics". Regarding the functional state of norms, Simmel prefers to speak of "lawfulness" (Gesetzlichkeit) in the legal sense instead of "law" in the sense of laws of nature. Consequently, Simmel's statements in the Law of the Individual can be considered consonant with his genetical approach to sociological research.

Simmel's Law of the Individual opens the way to fold social relations back into analysis of one's relationship with oneself and explains how forms of association are shaped by forms of self-relation. Thus, the theoretical gulf between Simmel's philosophy of life and his sociology, which commentators usually hold apart, becomes bridged. To be sure, normative conclusions cannot be deduced from descriptive premises. This would be a social fallacy analogous to the well-known naturalistic fallacy. But Simmel does not deduce "ought" from "is" of single actions but from the whole personality with emotional desires and intelligent devices. Consequently, social action is convenient if it is based on a realistic appraisal of human motivations which transcend the mere pleasure principle. The criterion of right and wrong is not as in Kant the logical consistency of the maxim but it is the self-image a person forms through living and loving. This corresponds to Simmel's statement that humans are the only beings which are able to combine natural determination with moral freedom.

In 1922, the German philosopher Rudolf Eucken, contemporary of Simmel, published an interesting comparison between Kantian and Confucian ethics [21]. The book shows that moral norms are of similar rigidity in Confucius and Kant. The gap between the Kantian world of freedom and Simmel's world of life is unbridgeable. Simmel follows the idea of freedom of the French philosopher Henri Bergson. In his Essay sur les donnés immediates de la conscience (1889), (Engl. Time and Free Will), Bergson describes the emergence of self-consciousness [22]. Ever since Descartes, philosophers have usually connected consciousness with reason and intelligence, neglecting its embeddedness in bodily experience and emotionality. In opposition to this Bergson suggests that the immediate data of consciousness, the absolute starting point, as it were, is "duration". Duration means not the length of time but a way of experiencing time. Based on this, Bergson concluded that freedom is not a breaking up of the chain of cause and effect but the concentration of all past moments in an extraordinary experience of presentational immediacy. In this primordial state of emotional intensity, objective time is cancelled out, and facing one's past and building one's future coincide. In his article Henri Bergson (1914) Simmel resumes Bergson's philosophy of life [23]. In life as a stream of consciousness the subject experiences inner freedom that overcomes mechanical determinism. The totality of the life history incites individuals to demonstrate self-valuation through an exemplary attitude toward others. Thus, the task of ethics is not to prescribe moral actions that ought to be done, but to describe the oftentimes dissonant emotional presuppositions of social behavior. 
Moral norms are bound to the experience of one's life-story with its subjective experiences and evaluations. In this sense Simmel can define the individual law as a function that is universal and private at the same time. This applies not only to social and political situations but to privacy. The human body is constantly sending out signals to its social companions. Among the overall signals of love the invitations to sexual intimacy are the most intense. In erotic love the sexual arousal transcends itself fantasizing like a religious feeling. In the late text Eros, Platonic and Modern Simmel holds tight to the primacy of individuality and points out the structural analogy between the individual law and erotic love: “... so there must be something like an individual law of eroticism in the incomparable relation between incomparable individuals" [8]. Thus, erotic life turns out to be at the root of concrete morality. However universal reason may be, human and especially female emotional intelligence is still more basic. In this respect culture is near to nature as the primordial root of social structures and functions.

From the discussion of Simmel's concrete ethics, it should be clear that he sees human experiences as permeated by conflicts. In this he follows modern philosophical anthropology. If we look to the East, the image of man in Chinese philosophy is less conflictive than western concepts of human nature. Chinese cultural anthropology is always a part of philosophical cosmology based on a harmonious world-order [19]. The main characteristic of humans is humaneness or benevolence (ren), the sense of which is not to be learned but innate.

\section{Conclusions}

As we have learned from Simmel, in modern societies life is in permanent conflict between nature and culture. Conflict is unavoidable and sometimes destructive, but at the same time it is the source of mental creativity. The conflicts inherent in erotic love in particular are constructive; they bring about unexpected forms of living and can thus be considered the royal road toward cultural diversity. From the genetical perspective, the main topics of Simmel's work are listed as follows and are compared with current Chinese sociology.

First: Simmel's method of sociological research differs from American sociology dominated by the sociologist Talcott Parsons, who considered society as a static structure. The close cooperation with American sociologists brought Chinese sociology forward, but also created limits regarding the genetic perspective. Here Simmel's concept of society emerging from the dynamic of personal interaction could be helpful for the process of modern individuation. Thus, the emancipation of Chinese sociology from the dominance of the American way of life would come to an end.

Second: Simmel's concept of culture in its close relation to sociality and the principle of reciprocity have become the standard. Chinese theory of culture starts from the unity of culture, and other cultures are considered as deviations of their own culture. Simmel's sociology of culture provides useful suggestions for how to cope with the one world that we live in now despite the plurality of 
cultural traditions. The advancement of culture is based on globalization as a process of real and ideal exchange and hence avoids the clash of culture that has become an urgent problem.

Third: Simmel's evaluation of erotic love was revolutionary in his time because it laid bare the unofficial and unacknowledged side of social life. Chinese theory of eroticism is dominated by patriarchal structures, the dominance of man over women. Here, Simmel's eroticism with its inherent drive to highlight the male-female polarity sets free creativity in intimate relations as well as in social life, creating opportunities for new forms of personal life.

Fourth: In modern ethics Simmel's principle of individuality and the formula of the individual law provide good arguments against the rigorism of the Kantian categorial imperative. Confucian virtue ethics focuses on the cultivation of benevolence, but the ethical teachings are ruled by patriarchal dominance. Here Simmel may help to overcome the ritual rigidity of the traditional social forms of life.

Fifth: Simmel's image of man is inherently problematic. This is different in Chinese anthropology. Of course, disturbances are acknowledged, but the essence of the human being is held as stable and harmonious. For Simmel, the cultural enrichment societies receive from competitive interaction of individuals with others results just because they are unequal in character traits and talents, thus breaking down ideological uniformity.

\section{Conflicts of Interest}

The author declares no conflicts of interest regarding the publication of this paper.

\section{References}

[1] Simmel, G. (1977) The Problems of the Philosophy of History. An Epistemological Essay. Translated and edited by Guy Oakes. The Free Press, New York.

[2] Wolff, K.H. (1950) The Sociology of Georg Simmel. Translated and edited by Kurt H. Wolff. The Free Press, Illinois.

[3] Frisby, D. (1997) Simmel on Culture. Selected Writings. Sage, London.

[4] Frisby, D. (2002) Georg Simmel. Revised Edition. Routledge, London and New York.

[5] Simmel, G. (2004) The Philosophy of Money. Edited by David Frisby. Translated by Tom Bottomore and David Frisby. Routledge, London and New York.

[6] Bian, Y.J. and Zhang, L. (2008) Sociology in China. Contexts Magazine, 7, 20-25. https://doi.org/10.1525/ctx.2008.7.3.20

[7] Weber, A. (1997) Kulturgeschichte als Kultursoziologie. Edited by Eberhard Demm. Metropolis-Verlag, Marburg.

[8] Simmel, G. (1971) On Individuality and Social Forms. Edited by Donald N. Levine. University of Chicago Press, Chicago.

[9] Simmel, G. (1968) The Conflict in Modern Culture and Other Essays. Translated by Peter Etzkorn. Teachers College Press, New York. 
[10] Tsang, A. and Lamont, M.J. (2018) How Can Cultural Sociology Help Us Understand Contemporary Chinese Society? The Journal of Chinese Sociology, 5, 15. https://doi.org/10.1186/s40711-018-0086-5

[11] Malinowski, B. (1960) Sex and Repression in Savage Society. Routledge \& Kegan Paul, London.

[12] Wilson, E.O. (1976) Sociobiology. The New Synthesis. The Belknap Press, Cambridge, MA.

[13] Fellmann, F. and Walsh, R. (2016) From Sexuality to Eroticism: The Making of the Human Mind. Advances in Anthropology, 6, 11-24. https://doi.org/10.4236/aa.2016.61002

[14] Simmel, G. (1984) On Women, Sexuality, and Love. Translated by Guy Oakes. Yale University Press, New Haven.

[15] Chiang, H. (2018) Sexuality in China: Histories of Power and Pleasure. University of Washington Press, Washington DC.

[16] Jeffreys, E. and Yu, H. (2015) Sex in China. Polity, Cambridge.

[17] Levine, D., Carter, E. and Miller Gorman, E. (1976) Simmel's Influence on American Sociology. In: Ästhetik und Soziologie um die Jahrhundertwende: Georg Simmel, Klostermann, Frankfurt a. Main, 175-228.

[18] Kant, I. (1969) Foundations of the Metaphysics of Morals. Translated by Lewis White Beck. Bobs-Merrill, Indianapolis.

[19] Xu, Y.X. (2006) Confucius. A Philosopher for the Ages. China Intercontinental Press, Beijing.

[20] Simmel, G. (2012) Lebensanschauung. Vier Metaphysische Kapitel. FV Edition, Wrozlaw.

[21] Eucken, R. and Chang, C. (1922) Das Lebensproblem in China und Europa. Quelle und Meyer, Leipzig.

[22] Bergson, H. (2001) Time and Free Will: An Essay on the Immediate Data of Consciousness. Dover Publications, London.

[23] Simmel, G. (1922) Henri Bergson (1914). Zur Philosophie der Kunst. Gustav Kiepenheuer, Potsdam. 